Check for updates

Cite this: RSC Adv., 2018, 8, 15876

Received 19th January 2018 Accepted 2nd April 2018

DOI: 10.1039/c8ra00577j

rsc.li/rsc-advances

\section{GIS-based evaluation of groundwater geochemistry and statistical determination of the fate of contaminants in shallow aquifers from different functional areas of Agra city, India: levels and spatial distributions}

\author{
Krishna Kumar Yadav, (DD *a Neha Gupta, (D) ${ }^{a}$ Vinit Kumar, ${ }^{a}$ Priya Choudhary ${ }^{b}$ \\ and Shakeel Ahmad Khan (D)
}

The quality of groundwater is very important in Agra because groundwater is the main source of water for drinking, domestic, agricultural and industrial uses. A groundwater geochemistry study was conducted in Agra where 28 samples were collected from shallow aquifers in May 2016 from different sites. The aim of this research was to assess the quality of groundwater for drinking purposes in the study area. Arc-GIS has been used to prepare geographic information system-based spatial distribution maps of different major elements. The groundwater quality was analyzed for various physico-chemical parameters, major cations and anions and some trace metals. The observed values were compared with BIS and WHO standards. Statistical parameters such as the mean, median, standard deviation, skewness and kurtosis were used to analyze the hydrogeochemical characteristics of the groundwater. Correlation coefficient analysis and principal component analysis (PCA) were performed to identify the sources of the water constituents. Our results showed that most of the samples exceeded the acceptable limit for drinking water standards. The sequence of abundance of the main cations was generally $\mathrm{Na}^{+}>\mathrm{Ca}^{2+}>\mathrm{Mg}^{2+}>\mathrm{K}^{+}$, while the anions in order of abundance were $\mathrm{HCO}_{3}{ }^{-}>\mathrm{Cl}^{-}>\mathrm{SO}_{4}{ }^{2-}$ and $\mathrm{NO}_{3}^{-}>\mathrm{F}^{-}$. All of the trace metals were within the permissible limit except for iron and manganese. The hazard index value of $5.7 \times$ $10^{-2}$ indicated that there was no potential health risk in the study area. $\mathrm{Ca}^{2+}, \mathrm{Mg}^{2+}, \mathrm{Cl}^{-}$and $\mathrm{SO}_{4}{ }^{2-}$ were the dominant hydrogeochemical facies in the majority of the groundwater samples. Most of the parameters such as TDS, $\mathrm{Cl}^{-}, \mathrm{HCO}_{3}{ }^{-}, \mathrm{SO}_{4}{ }^{2-}, \mathrm{NO}_{3}{ }^{-}, \mathrm{Ca}^{2+}, \mathrm{Mg}^{2+}, \mathrm{Na}^{+}, \mathrm{K}^{+}$and $\mathrm{TH}$ showed strong correlations with each other, which were due to natural processes such as weathering, exchangeable ions and reduction/oxidation, as well as anthropogenic activity around the study area. The water quality index indicated that the water quality was poor at $46.43 \%$ of the sampling sites, very poor at $28.57 \%$ of the sites and unsuitable for drinking purposes at $25 \%$ of the sampling sites. Gibbs diagrams suggested rock weathering as a major driving force for controlling the groundwater chemistry in the study area, along with evaporation as a minor influence.

\section{Introduction}

The quality of water is a vital concern for mankind as it is directly linked to human welfare. Groundwater, rivers, streams and wells are usual sources of drinking water which is usually untreated., ${ }^{\mathbf{1} 2}$ More than $90 \%$ of the Indian population from several states rely on groundwater for drinking and other purposes.,4 However, the indiscriminate use of chemical fertilizers, insecticides and pesticides, the improper disposal of

${ }^{a}$ Institute of Environment and Development Studies, Bundelkhand University, Jhansi, 284128, India. E-mail: envirokrishna@gmail.com; Tel: +91-9473949343

${ }^{b}$ Centre for Environment Science and Climate Resilient Agriculture, Indian Agricultural Research Institute, New Delhi, 110012, India waste, and chemical spills from industry have caused a deterioration in groundwater quality. ${ }^{5}$ Landfill leachate is also a significant source of groundwater pollution. ${ }^{6}$ Water quality is an important worldwide environmental issue and it involves a large number of physicochemical parameters, including heavy metals, anions and cations present in the groundwater. ${ }^{7}$ Heavy metal contamination is of great concern due to the toxicity, persistence and bioaccumulation of heavy metals. The accumulation of heavy metals above the threshold level is mainly due to anthropogenic activities including mining, chemical manufacturing and agriculture, and from hospital wastewater and electronic waste. ${ }^{8}$ Metals like copper, iron, manganese and zinc are essential for life processes, whereas others such as cadmium, nickel and mercury have no physiological functions 
but often result in harmful disorders at higher concentrations. ${ }^{\text {9-11 }}$ Mercury toxicity in humans can cause nervous, respiratory and renal damage. It is more toxic in its organic form, i.e. methyl mercury, when consumed or inhaled, while cadmium is highly toxic to the kidneys. Chronic exposure to arsenic may adversely affect the cardiovascular, renal, pulmonary, gastrointestinal, hepatic, neurological, reproductive and respiratory systems. It may also cause cancer in humans. ${ }^{12}$ Lead is one of the most toxic heavy metals that disturbs physiological processes in living beings. ${ }^{13} \mathrm{Cr}(\mathrm{vI})$ is also toxic to humans, while its reduced form, Cr(III), does not act as an essential contaminant in groundwater. ${ }^{\mathbf{1 4}}$ Groundwater chemistry provides a better understanding of possible alterations in its quality. It also determines its suitability for domestic and irrigation purposes. ${ }^{15}$ A number of studies on groundwater and surface water quality have been carried out in different parts of India and around the world through in terms of major ion chemistry, trace element chemistry and through multivariate statistical techniques. However, the characteristics of groundwater quality in Agra have not been investigated so far using multivariate statistical methodology. Prerna et al. ${ }^{\mathbf{1 6}}$ found that the concentration of $\mathrm{Fe}$ and $\mathrm{Mn}$ was higher than the permissible limit designated by the WHO and BIS in the Agra region. Kumar et al. ${ }^{17}$ evaluated the groundwater quality in the Agra district for irrigation purposes using Wilcox and Piper diagrams.

The present study uses statistical tools, including principal component analysis (PCA) and Pearson correlation matrices, to resolve and interpret the complex dataset. On the other hand, the water quality index has been evaluated to assess the drinking water quality and suitability in the area. The hydrochemical facies have been classified with the support of Piper trilinear diagrams to determine the chemical characteristics of groundwater in Agra. The average daily dose and hazard quotient were calculated to assess the health risk associated with the ingestion of trace metals present in groundwater in the study area. However, the objective of this paper is to develop a reliable multi-statistical method to characterize the water quality of groundwater samples in Agra, which will be useful for decision makers to take the proper initiative for groundwater quality management.

\section{Materials and methods}

\subsection{Study area}

Agra is a city where one of the seven wonders is located, known as the Taj Mahal. The city lies in Western Uttar Pradesh, situated on the banks of the Yamuna river, $185 \mathrm{~km}$ southeast of New Delhi. The average elevation of the study area was around $169 \mathrm{~m}$ above sea level, and the city lies at $27^{\circ} 10^{\prime} \mathrm{N}$ and $78^{\circ} 02^{\prime} \mathrm{E}$, as shown in Fig. 1. The total area of Agra district is $4041 \mathrm{~km}^{2}$, of which $279.998 \mathrm{~km}^{2}$ of urban area was sampled in this study. According to the national census of 2011, the total population of the city is 4418797 (http://upenvis.nic.in/Database/ Agra_930.aspx). The city experiences various seasons such as mild winters, dry and hot summers and monsoon seasons. The climate of the city is a semi-arid to subtropical climate. The temperature rises from $21.9{ }^{\circ} \mathrm{C}$ to $45{ }^{\circ} \mathrm{C}$ in the summer and

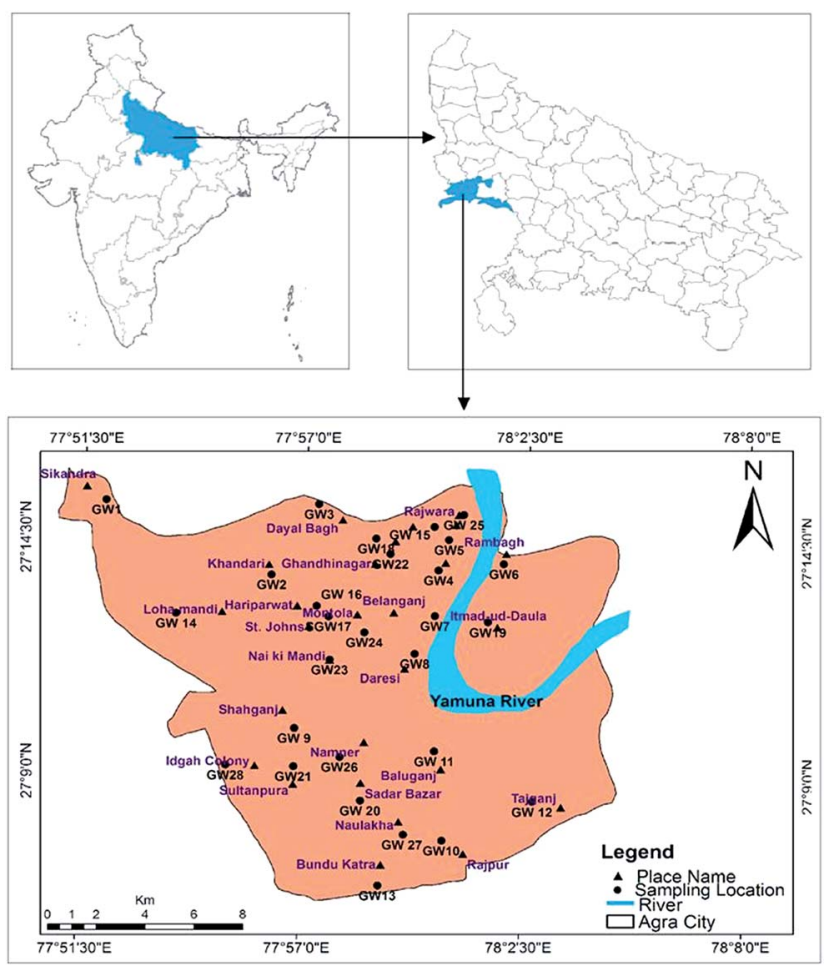

Fig. 1 Agra city map showing groundwater sampling locations.

drops to $4.2{ }^{\circ} \mathrm{C}$ in the winter. The mean annual rainfall is 687.2 $\mathrm{mm},{ }^{18} 95 \%$ of which is expected to come from a southwest monsoon in July to September, with an average evapotranspiration rate of $1466 \mathrm{~mm}$ per year. The daily relative humidity varies from 30 to $100 \%$. Agra is a major tourist destination and approximately 7200 small-scale industrial units are also established. The economy is dependent on the industrial sector, which includes automobiles, leather goods, handicrafts and stone carving. There has been rapid exploitation of the groundwater resources during the last decade. Additionally, large scale pollution has occurred due to pressure from the increased industrialization and urbanization and the increase in population.

\subsection{Hydrogeology of the area}

The Agra region occupies a part of the Indo-Gangetic plains with quaternary sediments, which mainly comprise a sequence of clay, silt, different grades of sand, gravel and kankar $\left(\mathrm{CaCO}_{3}\right.$ concretions) in varying proportions. ${ }^{19,20}$ Sedimentary formations were deposited when the valley filled unconformably on the Vindhyan sandstones during the middle to late Pleistocene and Holocene times. These comprise different grades of sand, silt, clay, gravel and secondarily developed calcareous nodules known as kankar. The majority of the region is comprised of quaternary age alluvium. The alluvium was deposited over a base of Vindhyan rocks, e.g. sandstone, shale, silt stone, etc. Broad horizons of arkosic gravel/coarse sand are present just above the basal formations in the lower part. ${ }^{20}$ Vindhyan rock formations consist of rocks of the Bhander group, which 
include white to purple quartz arenite, medium to fine-grained purplish to reddish spotted and laminated sandstone with intermittent deposits of shales, shale pebble conglomerate, siltstone and greenish sandstone. ${ }^{18}$ Due to the varied hydrogeochemical conditions and significant dissimilarities in lithologies and climatic conditions, the geological formation is highly diversified, which further complicates the study of groundwater behavior. ${ }^{21}$ Groundwater occurs mostly in the study area in weathered and fractured zones of unconsolidated sediments. The weathered zones are confined, whereas the fractured zones are semi-confined aquifers. ${ }^{22}$ Semi-confined aquifers are the active recharge zones and contain replenishable groundwater resources. The entire area may broadly be classified into two zones: the western part of the area, with a comparatively shallow depth of the water table, and the eastern part of the area along the Yamuna river, with a deeper water table. The depth of groundwater in Agra differs from 17 to $23 \mathrm{~m}$ below ground level (bgl), but it may vary nearby the Agra canal and Yamuna river, and in topographic lows.

\subsection{Collection of water samples}

The systematic random method was adopted for the collection of 28 groundwater samples from shallow aquifers via existing tube wells or hand pumps based on their availability in the sampling locations cited in the urban area of Agra city. The samples were collected in May 2016. The water from tube wells is used as drinking water without any prior treatment. Hand pumps of $50 \mathrm{~m}$ depth were used for the collection of water samples. Depths were determined through interviews with private well owners. The average groundwater table depth in the study area was $20 \mathrm{mbgl}$ according to the Ground Water Department, Uttar Pradesh. ${ }^{23}$ The water samples were collected only after pumping water for at least $30 \mathrm{~min}$ from the tube wells, while the hand pumps were operated for 10-20 min prior to the collection of samples. The water was allowed to flow out in order to obtain stabilized values for temperature, $\mathrm{pH}$ and DO. Samples with a total volume of $1 \mathrm{~L}$ were collected in polypropylene bottles which were previously rinsed twice with deionized water. Separate samples were collected in $25 \mathrm{ml}$ small bottles for the estimation of trace metal content, and they were preserved at $\mathrm{pH} 2$ with $1 \% \mathrm{HNO}_{3}$. After the collection, the sample bottles were stored in an ice box in the field and taken to the laboratory, where they were kept in a refrigerator at a temperature of $4{ }^{\circ} \mathrm{C}$.

\subsection{Experimental analysis}

The pH, EC and TDS values were measured on-site immediately after the collection of the samples using a portable meter. The remaining parameters were determined within 2 weeks in the laboratory. Turbidity was measured using a multi-meter water checker (Horiba U-10) in Nephelometric units (NTUs). Total hardness (TH) in terms of $\mathrm{CaCO}_{3}, \mathrm{HCO}_{3}{ }^{-}$and $\mathrm{Cl}^{-}$content was analyzed by the volumetric titration method described by the American Public Health Association (APHA). ${ }^{24}$ The average values of three measurements were calculated for each sample. Dissolved oxygen (DO) was determined using a DO data meter
(Eutech CyberScan DO 3000). Concentrations of the major cations (including $\mathrm{Ca}^{2+}, \mathrm{Mg}^{2+}, \mathrm{Na}^{+}, \mathrm{K}^{+}$) were measured using a flame photometer (JAISBO Microprocessor). Fluoride anion content was determined by the SPADNS method using a UV-vis spectrophotometer (UV-2450, Shimadzu) at $570 \mathrm{~nm}$. Nitrate and sulphate content were also analyzed using a spectrophotometer at $220 \mathrm{~nm}$ and $420 \mathrm{~nm}$, respectively. Major trace metal ( $\mathrm{Zn}, \mathrm{Cu}$, Fe and $\mathrm{Mn}$ ) content was measured in $\mathrm{mg} \mathrm{L}^{-1}$ with the use of an atomic absorption spectrophotometer (AA-7000, Shimadzu) in flame mode after calibration of the respective elements with the specific known standards. Statistical analysis was used to apportion the sources of the contaminants in the water, while a geographical information system (GIS) was used to prepare the geochemical distribution maps.

\subsection{Quality assurance and quality control}

Appropriate protocols for well-purging were used and the accuracy of all analyses was measured using externally supplied standards and calibration check standards, with known additions of the standard to samples and reagent blanks. To ensure the precision of the results, three replicas of the samples were analyzed. All reagents were purchased from Merck. The percent relative standard deviation (RSD) was found to be below $10 \%$, which represents the overall precision for all of the assessed samples examined at the Centre for Environment Science and Climate Resilient Agriculture, Indian Agricultural Research Institute (IARI), New Delhi.

\subsection{Quantitative health risk assessment}

Human exposure to trace metals could occur through three pathways, including oral ingestion, inhalation through the nose and dermal absorption through the skin. The health risks associated with the ingestion of trace metals present in groundwater were assessed using the average daily dose and hazard quotient parameters. The ADD for each trace metal was calculated using eqn (1) adapted from USEPA: ${ }^{25}$

$$
\mathrm{ADD}=\frac{(C \times \mathrm{IR} \times \mathrm{EF} \times \mathrm{ED})}{(\mathrm{BW} \times \mathrm{AT})}
$$

where ADD is the average daily dose ( $\mathrm{mg}$ per $\mathrm{kg}$ per day), $C$ is the average concentration of the trace metal in groundwater $(\mathrm{mg}$ $\left.\mathrm{L}^{-1}\right)$, IR is the ingestion rate ( $2 \mathrm{~L}$ per day), $\mathrm{EF}$ is the exposure frequency (365 days per year), ED is the exposure duration (70 years), BW is the body weight (70 kg) and AT is the average time $(\mathrm{EF} \times \mathrm{ED})$.

The hazard quotient (HQ) for the potential non-carcinogenic risk from each trace metal was determined by dividing the calculated ADD by the reference dose (RfD) using eqn (2):

$$
\mathrm{HQ}=\frac{\mathrm{ADD}}{\mathrm{RfD}}
$$

where RfD is the oral toxicity reference dose (mg per kg per day). The value of the RfD for each trace metal was obtained from USEPA. ${ }^{26} \mathrm{HQ}<1$ is considered to be safe and non-carcinogenic for human health, but $\mathrm{HQ}>1$ may be a major potential health concern. 


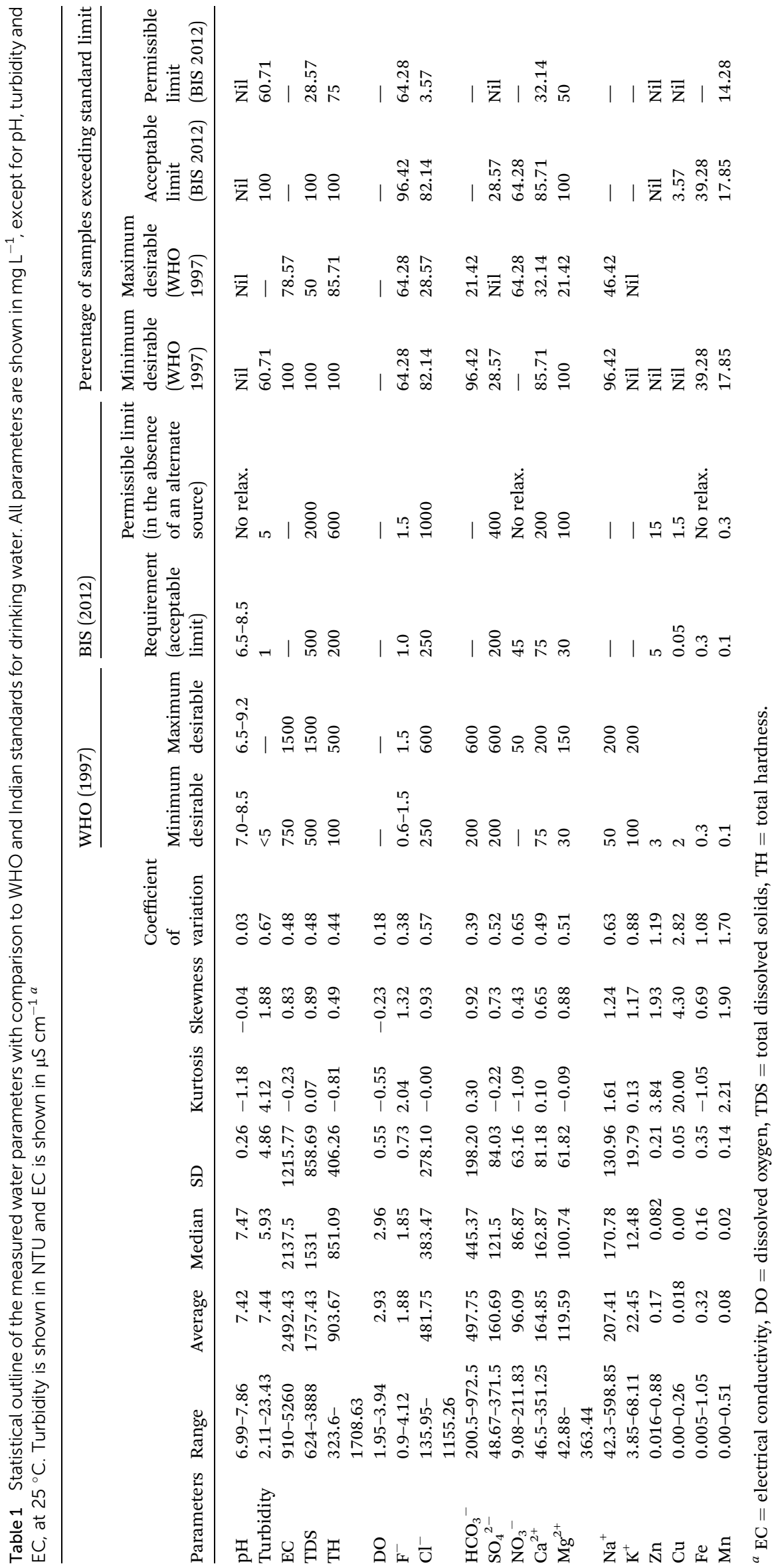


The overall potential non-carcinogenic risk posed by all metals was assessed by adding their respective HQ values using eqn (3). The sum of the HQ values of all metals was termed the hazard index (HI). A value of $\mathrm{HI}>1$ is assumed to have a potential adverse effect on human health. ${ }^{27}$

$$
\mathrm{HI}=\mathrm{HQ}_{\mathrm{Zn}}+\mathrm{HQ}_{\mathrm{Cu}}+\mathrm{HQ}_{\mathrm{Fe}}+\mathrm{HQ}_{\mathrm{Mn}}
$$

\subsection{Water quality index (WQI) for groundwater quality}

Water quality index is a very useful, effective and efficient tool to communicate information on the overall quality of water. ${ }^{28}$ The estimation of the WQI helps in determining the suitability of groundwater for drinking purposes. Many authors and organizations employ the WQI to meet specific requirements and to express the condition of water. ${ }^{29-32}$ The index reduces large datasets to a single value, facilitating the understanding of the information. The method used for the calculation of the WQI was adapted from Sharma et al. ${ }^{33}$ A total of 15 parameters $(\mathrm{pH}$, turbidity, TDS, $\mathrm{F}^{-}, \mathrm{Cl}^{-}, \mathrm{NO}_{3}{ }^{-}, \mathrm{SO}_{4}{ }^{2-}, \mathrm{HCO}_{3}{ }^{-}, \mathrm{Ca}^{2+}, \mathrm{Mg}^{2+}$, total hardness, $\mathrm{Zn}, \mathrm{Cu}, \mathrm{Fe}$ and $\mathrm{Mn}$ ) were considered to calculate the WQI. Each parameter was assigned a definite weight $\left(\mathrm{w}_{i}\right)$ according to its relative importance on the overall quality of water, ranging from 1 to 5 (Table 6), where 5 was considered most significant while 1 was least significant. In the second step, the relative weight $\left(W_{i}\right)$ was computed using eqn (4):

$$
W_{i}=w_{i} / \sum_{i=1}^{n} w_{i}
$$

where $W_{i}$ is the relative weight, $w_{i}$ is the weight of each parameter and $n$ is the number of parameters.

In the next step, the quality rating scale $\left(q_{i}\right)$ was measured by comparing the concentration of each parameter in the sample with its respective standard value, as suggested in the BIS guidelines:

$$
q_{i}=\frac{C_{i}}{S_{i}} \times 100
$$

where $q_{i}$ is the quality rating scale, $C_{i}$ is the measured concentration of each parameter in $\mathrm{mg} \mathrm{L}^{-1}$, and $S_{i}$ is the standard value for each parameter according to $\mathrm{BIS}^{34}$ in $\mathrm{mg} \mathrm{L}^{-1}$.

Sub-indices (SI) were calculated to compute the WQI in the next step using eqn (6).

$$
\mathrm{SI}_{i}=W_{i} \times q_{i}
$$

In final step, the WQI was calculated using eqn (7).

$$
\mathrm{WQI}=\sum \mathrm{SI}_{i}
$$

\subsection{Statistical analysis}

The mean, range, median, standard deviation, skewness, coefficient of variation, kurtosis and correlation coefficient for different parameters were calculated using Microsoft Excel
2010. The Statistical Package for Social Science (SPSS) software was used for principal component analysis (PCA) and the correlation coefficient was determined in order to identify the sources of different elements in the groundwater sample, as well as inter-element correlation. PCs were extracted by varimax rotation, which selects the variable with the maximum contribution by increasing its participation whilst simultaneously reducing participation of the less contributing variable.

ArcGIS 10.2 software was used to obtain the spatial distribution of the groundwater quality parameters. ArcGIS is a tool which creates layered and spatial maps by analyzing a geographic information database. An inverse distance weighted (IDW) interpolation technique was used for spatial modelling. This technique calculates a value for each grid node by examining the surrounding data points that lie within a userdefined search radius. ${ }^{35}$ All of the data points are used in the interpolation process, and the node value is calculated by averaging the weighted sum of all of the points (Table 1 ).

\section{Results and discussion}

\subsection{Hydrochemistry of the physicochemical parameters}

The measured physicochemical parameters are summarized statistically and compared with the WHO and BIS standards in Table 1. The $\mathrm{pH}$ values ranging from 6.99 to 7.86 , with an average value of 7.42 , showed neutral to slightly alkaline dominance in the groundwater of the study area. The turbidity ranged from 2.11 to $23.43 \mathrm{NTU}$, with an average of $7.44 \mathrm{NTU}$, where $61 \%$ of the water samples exceeded the recommended value of 5 NTU. Drinking water standards do not mandate measurement of dissolved oxygen (DO), but the DO concentration provides meaningful information regarding the stability of many organic and inorganic contaminants in the groundwater. ${ }^{36}$ The mean value of DO concentration was $2.93 \mathrm{mg} \mathrm{L}^{-1}$, with minimum and maximum values of $1.95 \mathrm{mg} \mathrm{L}^{-1}$ and $3.94 \mathrm{mg} \mathrm{L}^{-1}$, respectively. The measured electrical conductivity (EC) ranged from $910 \mu \mathrm{S} \mathrm{cm} \mathrm{cm}^{-1}$ to $5260 \mu \mathrm{S} \mathrm{cm} \mathrm{cm}^{-1}$, where $78 \%$ of the samples exceeded the permissible limit designated by the

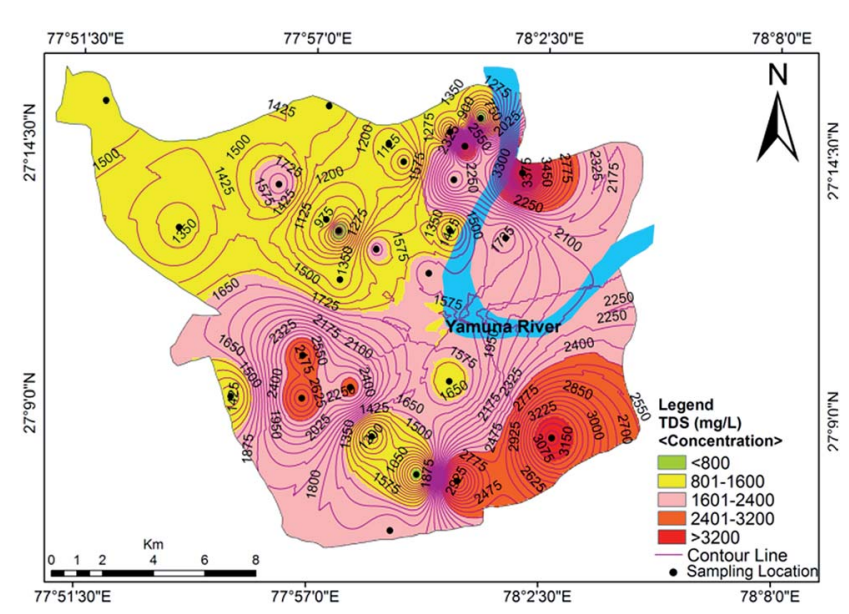

Fig. 2 Concentration contour map for TDS showing spatial variation in the groundwater of the study area. 
WHO. ${ }^{37}$ High EC values indicate a high ion concentration and/ or a high content of dissolved solids in the groundwater. This also signifies multiple a aquifer system and local variation in the soil type. ${ }^{17}$ The value of total dissolved solids (TDS) varied from $624 \mathrm{mg} \mathrm{L}^{-1}$ to $3888 \mathrm{mg} \mathrm{L}^{-1}$ with an average of $1757 \mathrm{mg} \mathrm{L}^{-1}$. The TDS exceeded the desirable limit in $100 \%$ of the water samples, but $50 \%$ of the samples met the permissible level designated by the $\mathrm{WHO}^{37}$ standards for drinking water. The spatial distribution of TDS is shown in Fig. 2. A high spatial variation of EC and TDS is evidence for the heterogeneity of the water chemistry and the involvement of different types of processes. Approximately $75 \%$ of the groundwater samples were slightly saline to moderately saline (Table 2) on the basis of groundwater classification and were not suitable for drinking purposes. The high TDS results from the discharge of municipal and industrial effluents, industrial seepage and the percolation of channel water containing solids.

Hardness refers to the total concentration of dissolved calcium and magnesium in water. Water is classified as soft, hard, moderately hard and very hard in context of hardness (Sawyer and $\mathrm{McCarty}^{39}$ ). The total hardness (TH) of the analyzed groundwater samples ranged from $323 \mathrm{mg} \mathrm{L}^{-1}$ to $1708 \mathrm{mg} \mathrm{L}^{-1}$ with a mean value of $903 \mathrm{mg} \mathrm{L}^{-1}$. Classification of the groundwater quality in the study area on the basis of hardness content (Table 2) indicated that all of the samples were very hard in nature. The data showed that the hardness of all of the samples exceeded the acceptable limit designated by the BIS and WHO standards, but approximately $25 \%$ of samples were under the permissible limit (Fig. 3). Hard water is not desirable for domestic uses because it can cause metal corrosion due to scaly deposition inside pipes, boilers and tanks. It also potentially contributes to a decrease the perceived quality of water, and could pose a danger to human health, causing conditions

Table 2 Groundwater classification on the basis of total dissolved solids (TDS) and total hardness (TH)

\begin{tabular}{|c|c|c|c|c|c|}
\hline \multirow[b]{2}{*}{ S. no. } & \multirow{2}{*}{$\begin{array}{l}\text { Class of } \\
\text { groundwater }\end{array}$} & \multirow{2}{*}{$\begin{array}{l}\text { Range of TDS/TH } \\
\left(\mathrm{mg} \mathrm{L}^{-1}\right)\end{array}$} & \multicolumn{2}{|c|}{ Samples } & \multirow{2}{*}{$\begin{array}{l}\text { Sample } \\
\text { number }\end{array}$} \\
\hline & & & No. & $\%$ & \\
\hline \multicolumn{6}{|c|}{ Total dissolved solids (Selvakumar et al. $^{38}$ ) } \\
\hline 1 & Fresh water & $<1000$ & 4 & 14.28 & $15,17,25,28$ \\
\hline 2 & Slightly saline & $1000-3000$ & 21 & 75 & $\begin{array}{l}1,2,3,4,5,7, \\
8,9,11,13,14, \\
16,18,19,20, \\
21,22,23,24, \\
26,28\end{array}$ \\
\hline 3 & $\begin{array}{l}\text { Moderately } \\
\text { saline }\end{array}$ & $3000-10000$ & 3 & 10.71 & $6,10,12$ \\
\hline 4 & Very saline & $10000-30000$ & Nil & Nil & Nil \\
\hline 5 & Brine & $>30000$ & Nil & Nil & Nil \\
\hline \multicolumn{6}{|c|}{ Total hardness (Sawyer and McCarty ${ }^{39}$ ) } \\
\hline 1 & Soft & $<75$ & Nil & Nil & Nil \\
\hline 2 & $\begin{array}{l}\text { Moderately } \\
\text { hard }\end{array}$ & $75-150$ & Nil & Nil & Nil \\
\hline 3 & Hard & $150-300$ & Nil & Nil & Nil \\
\hline 4 & Very hard & $>300$ & 28 & 100 & All samples \\
\hline
\end{tabular}

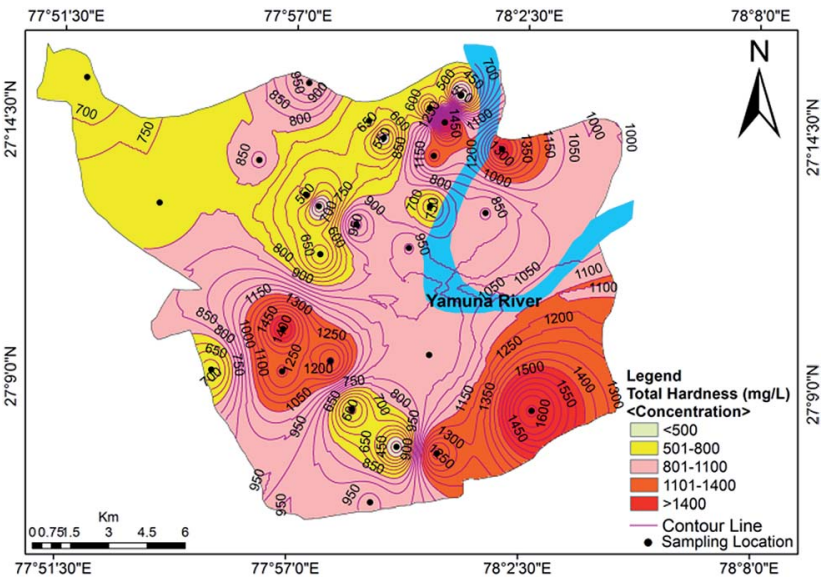

Fig. 3 Concentration contour map for the total hardness showing spatial variation in the groundwater of the study area.

such as urolithiasis, anencephaly, prenatal mortality, some types of cancer and cardiovascular diseases. ${ }^{29}$

\subsection{Major anions and cations in groundwater}

Cation analysis showed that the order of concentration of the cations was $\mathrm{Na}^{+}>\mathrm{Ca}^{2+}>\mathrm{Mg}^{2+}>\mathrm{K}^{+}$, with contributions of $40 \%$, $32 \%, 23 \%$ and $5 \%$, respectively. Calcium content varied from a minimum value of $46.50 \mathrm{mg} \mathrm{L}^{-1}$ to a maximum value of $351.25 \mathrm{mg} \mathrm{L}^{-1}$, with an average of $41.4 \mathrm{mg} \mathrm{L}^{-1}$. Approximately $85.71 \%$ of the samples exceeded the acceptable limit of $75 \mathrm{mg} \mathrm{L}^{-1}$, while $32.14 \%$ of the samples exceeded the permissible limit of $200 \mathrm{mg} \mathrm{L}^{-1}$. The concentration of $\mathrm{Mg}^{2+}$ varied between $42.88 \mathrm{mg} \mathrm{L}^{-1}$ and $363.44 \mathrm{mg} \mathrm{L}^{-1}$ (avg. $119.59 \mathrm{mg} \mathrm{L}^{-1}$ ). The $\mathrm{Ca}^{2+}$ concentration exceeded the $\mathrm{Mg}^{2+}$ concentration at many sites, indicating a major supply of limestone, sedimentary rocks and calcium-bearing minerals. A tolerable upper limit is $2500 \mathrm{mg}$ per day for calcium and $350 \mathrm{mg}$ per day for magnesium, above which habitual intake may cause adverse health effects in adults. ${ }^{40}$ The concentrations of $\mathrm{Na}^{+}$and $\mathrm{K}^{+}$ions varied

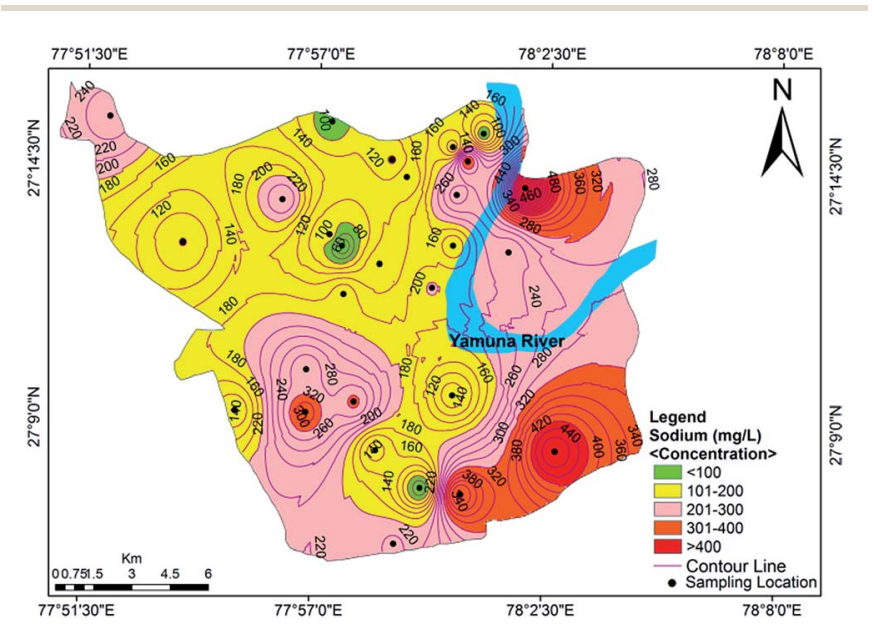

Fig. 4 Concentration contour map for sodium showing spatial variation in the groundwater of the study area. 
from 42.30 to $598.85 \mathrm{mg} \mathrm{L}^{-1}$ (mean value of $207.41 \mathrm{mg} \mathrm{L}^{-1}$ ) and 3.85 to $68.11 \mathrm{mg} \mathrm{L}^{-1}$ (mean value of $22.45 \mathrm{mg} \mathrm{L}^{-1}$ ), respectively. Approximately $16 \%$ of the samples were observed to have a high concentration of sodium compared to the WHO standards. ${ }^{37} \mathrm{~A}$ sodium content above the desirable limit can cause hypertension, heart problems, nervous system diseases and kidney diseases. ${ }^{41}$ The spatial distribution map for $\mathrm{Na}^{+}$is shown in Fig. 4. The main sources of potassium in groundwater include rainwater and the weathering of potash and silicate minerals, and there is no recommended standard for the upper level of $\mathrm{K}^{+}$ in drinking water.

The anions in order of decreasing concentration were $\mathrm{HCO}_{3}{ }^{-}$ $>\mathrm{Cl}^{-}>\mathrm{SO}_{4}{ }^{2-}>\mathrm{NO}_{3}{ }^{-}>\mathrm{F}^{-}$, with contributions of $40 \%, 39 \%$, $13 \%, 8 \%$ and below $1 \%$, respectively. The range of $\mathrm{HCO}_{3}{ }^{-}$ concentration in the study area was $200.5-972.5 \mathrm{mg} \mathrm{L}^{-1}$ with a mean value of $497.75 \mathrm{mg} \mathrm{L}^{-1}$. The presence of bicarbonates in soil results from the dissolution of carbonates and silicates by carbonic acid. The chloride concentration was found to be higher than the $\mathrm{HCO}_{3}{ }^{-}$concentration, which infers that the dissolution of minerals has taken place in the study area. The chloride content exceeded the desirable limit of $250 \mathrm{mg} \mathrm{L}^{-1}$ in $82.14 \%$ of the samples, which may impart a noticable salty taste in the groundwater. The higher concentrations of chloride may be due to the weathering of rock, atmospheric deposition, landfill leachates, septic tank effluents, poor sanitary conditions, chemical fertilizers and industrial effluents in sewage. ${ }^{42}$ The concentration of $\mathrm{SO}_{4}{ }^{2-}$ in the studied samples varied between $48.67-371.5 \mathrm{mg} \mathrm{L}^{-1}$, with an average value of $160.69 \mathrm{mg} \mathrm{L}^{-1}$. It is ubiquitous in groundwater and does not pose a health risk at the levels normally found in drinking water. However, its higher concentration in drinking water indicates a deteriorating water quality which may cause a health risk. It is commonly derived from the oxidative weathering of sulphide minerals such as pyrite $\left(\mathrm{FeS}_{2}\right)$. However, gypsum and anhydrite are also significant sources of sulphate in water. ${ }^{43}$ The sulphate concentrations were below the permissible limit in all of the investigated samples except for $4,5,6,10,13$ and 21 . The nitrate content varied from

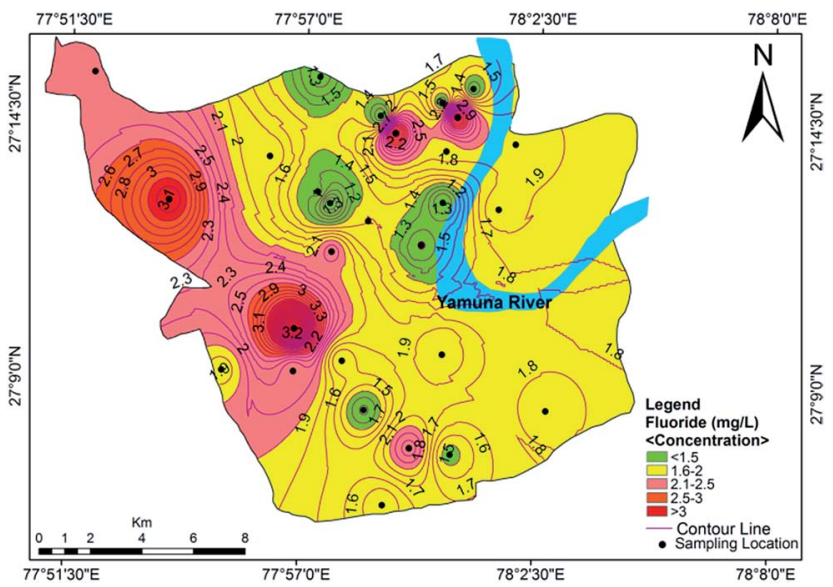

Fig. 5 Concentration contour map for fluoride showing spatial variation in the groundwater of the study area.
Table 3 Characteristics of water in each zone of the Piper trilinear diagram

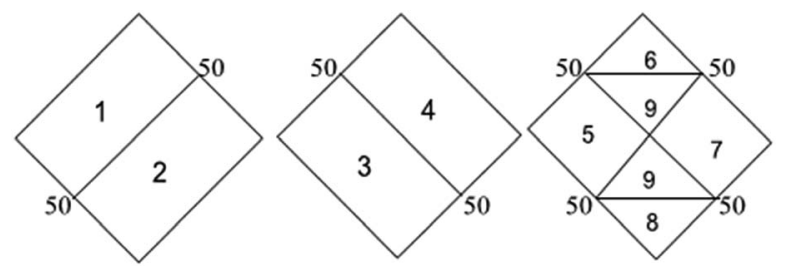

Zone Characteristics of water

$\begin{array}{ll}1 & \text { Alkaline earth }(\mathrm{Ca}+\mathrm{Mg}) \text { exceeds alkali }(\mathrm{Na}+\mathrm{K}) \\ 2 & \text { Alkali exceeds alkaline earth } \\ 3 & \text { Weak acid }\left(\mathrm{CO}_{3}+\mathrm{HCO}_{3}\right) \text { exceeds strong acid }\left(\mathrm{SO}_{4}+\mathrm{Cl}\right) \\ 4 & \text { Strong acid exceeds weak acid } \\ 5 & \text { Carbonate hardness (secondary alkalinity) exceeds } 50 \% \\ 6 & \text { Non-carbonate hardness (secondary salinity) exceeds } 50 \% \\ 7 & \text { Non-carbonate alkali (primary salinity) exceeds } 50 \% \\ 8 & \text { Carbonate alkali (primary alkalinity) exceeds } 50 \% \\ 9 & \text { No one cation-anion pair exceeds } 50 \%\end{array}$

$9.08 \mathrm{mg} \mathrm{L}^{-1}$ to $211.83 \mathrm{mg} \mathrm{L} \mathrm{L}^{-1}$, with a mean value of $96.09 \mathrm{mg} \mathrm{L}^{-1}$. About $64.28 \%$ of the samples exceeded the WHO guideline level for nitrate in drinking water. Anthropogenic activity, such as septic tanks, seepage beds, municipal or domestic sewage and nitrogenous waste are the sources of nitrate contamination in the study area. Groundwater sources have been affected by seepage along the Yamuna river and the apparent surface water-groundwater interactions. Excessive $\mathrm{NO}_{3}{ }^{-}$in drinking water can cause some disorders including methemoglobinemia in infants, gastric cancer, goiter and hypertension in adults. ${ }^{44}$ Therefore, several researchers used various methods for its removal from

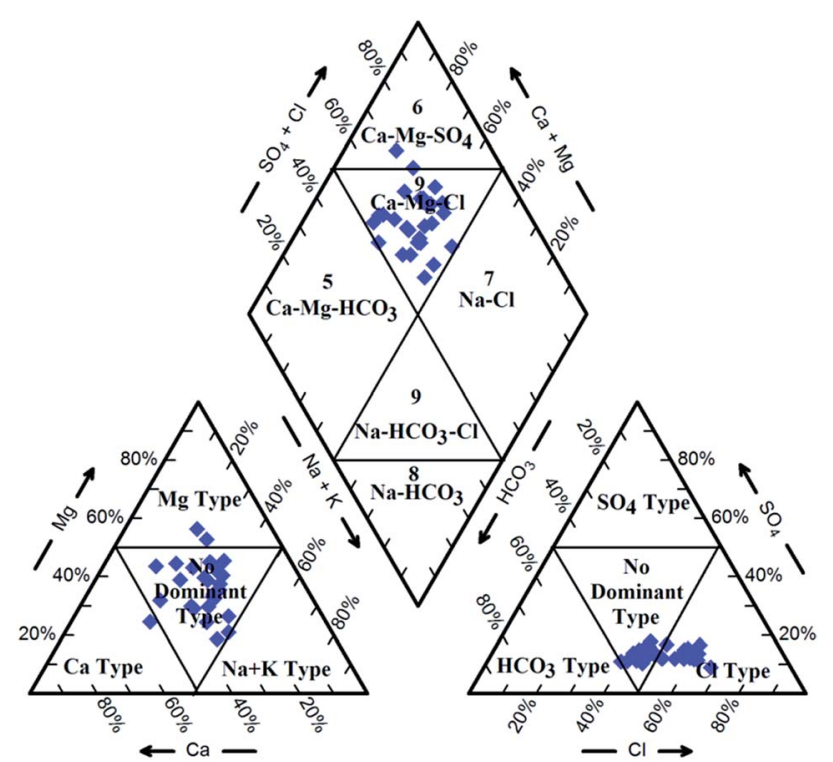

Fig. 6 Piper trilinear diagram showing hydrogeochemical character and hydrochemical facies in the groundwater of Agra city. 


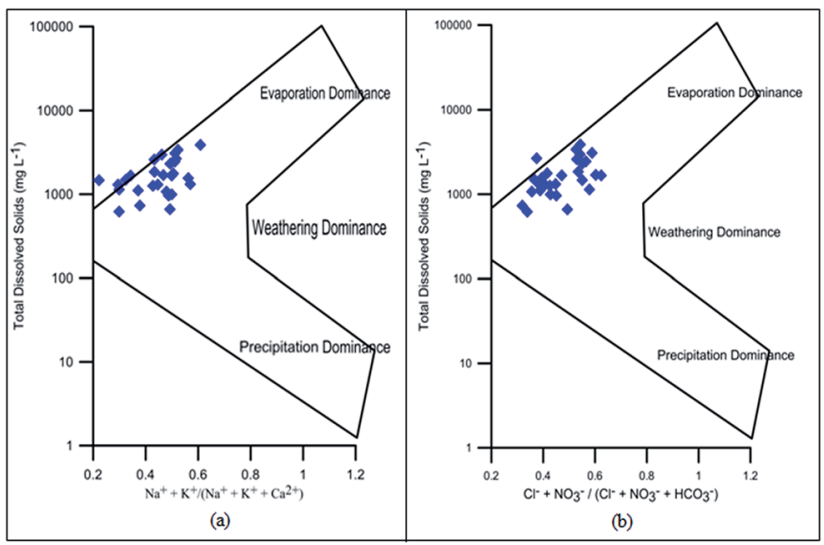

Fig. 7 Gibbs diagram representing the ratio of (a) $\mathrm{Na}^{+}+\mathrm{K}^{+} /\left(\mathrm{Na}^{+}+\right.$ $\left.\mathrm{K}^{+}+\mathrm{Ca}^{+}\right)$and (b) $\mathrm{Cl}^{-}+\mathrm{NO}_{3}^{-} /\left(\mathrm{Cl}^{-}+\mathrm{NO}_{3}{ }^{-}+\mathrm{HCO}_{3}{ }^{-}\right)$as a function of TDS.

groundwater. ${ }^{45-47}$ The fluoride content was higher than the guideline value designated by $\mathrm{WHO}^{37}$ and $\mathrm{BIS}^{34}$ in $64.28 \%$ of the samples. The highest concentration of $4.12 \mathrm{mg} \mathrm{L}^{-1}$ was reported at Shahganj, which has potential to cause fluorosis with long-term damage to the brain, liver, thyroid and kidneys. ${ }^{48,49}$ The spatial distribution of fluoride in the groundwater of the study area is shown in Fig. 5 . The source of fluoride is mostly natural, from the disintegration of rocks and soils or the weathering of fluoride-bearing minerals such as florahalite ore and fluorite. However, there are also other sources of fluoride in groundwater such as industrial waste, municipal solid waste dumping and the seepage of untreated sewage water into the Yamuna river.

\subsection{Concentration of trace metals in groundwater}

Table 1 shows the mean concentration of different trace metals in groundwater samples along with other relevant statistical distribution parameters. The investigated trace metals in order of decreasing mean concentration were $\mathrm{Fe}>\mathrm{Zn}>\mathrm{Mn}>\mathrm{Cu}$. Iron concentrations spanned a wide range of $0.005-1.05 \mathrm{mg} \mathrm{L}^{-1}$, with an average value of $0.32 \mathrm{mg} \mathrm{L}^{-1}$. Iron primarily occurs naturally in soils, rocks and minerals, but some anthropogenic sources such as industrial effluents, sewage landfill leachate and the dissolution of iron from ferrous boreholes and hand pumps may also contribute to elevating the iron level in groundwater. The iron concentration exceeded the recommended BIS level in $39.28 \%$ of the samples. The highest concentration of $1.05 \mathrm{mg} \mathrm{L}^{-1}$ was observed at Sultanpura. The concentration of iron available in water does not threaten human health, but adverse health effects may occur due to chronic ingestion of high concentrations of iron. ${ }^{50}$ The concentration of $\mathrm{Zn}$ varied from $0.016-0.88 \mathrm{mg} \mathrm{L}^{-1}$ with an average value of $0.17 \mathrm{mg} \mathrm{L}^{-1}$. Zinc poisoning, which causes nausea, abdominal cramping, vomiting, tenesmus and diarrhea with or without bleeding, is associated with high levels of zinc concentration in drinking water. ${ }^{51}$ However, $\mathrm{Zn}$ concentrations were under the recommended limit designated by the BIS and WHO in all of the samples. The manganese concentration in the groundwater samples varied from BDL-0.51 $\mathrm{mg} \mathrm{L}^{-1}$ (avg. $0.08 \mathrm{mg} \mathrm{L}^{-1}$ ). About $17.85 \%$ of the samples exceeded the acceptable limit $\left(0.1 \mathrm{mg} \mathrm{L}^{-1}\right)$ designated by BIS and WHO. The most common source of manganese in groundwater is the natural weathering of manganese-bearing minerals. Industrial effluents, sewage and landfill leachate are some anthropogenic sources which may raise manganese concentration in groundwater. Manganese does not threaten human health at a normal concentration in drinking water. However, a higher concentration of manganese may affect learning ability and intelligence quotient in children, while neurological damage, resulting in Parkinson's-like symptoms, emotional liability and hallucinations are symptoms of manganese over-exposure in adults. ${ }^{52}$ Copper is an essential element for living organisms including

Table 4 Inter-elemental correlation matrix of dissolved ions $(n=28)$

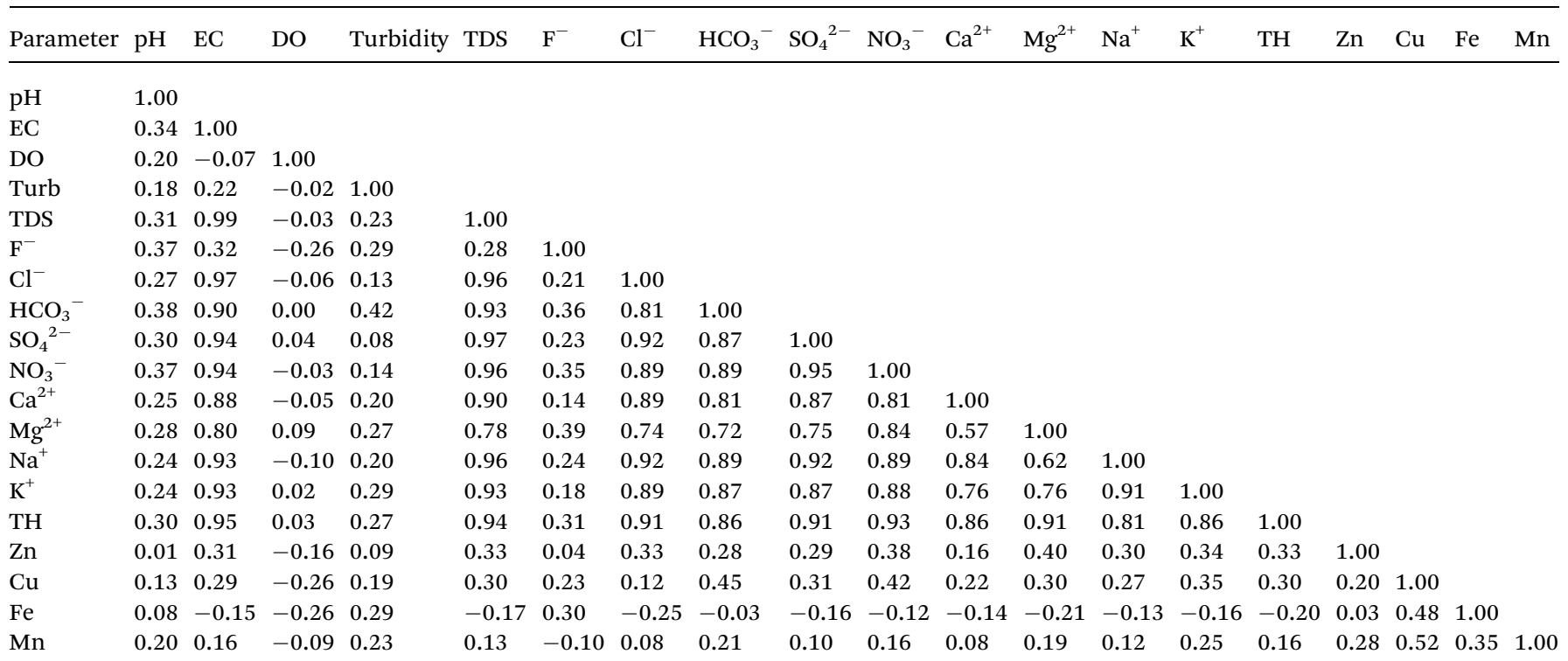




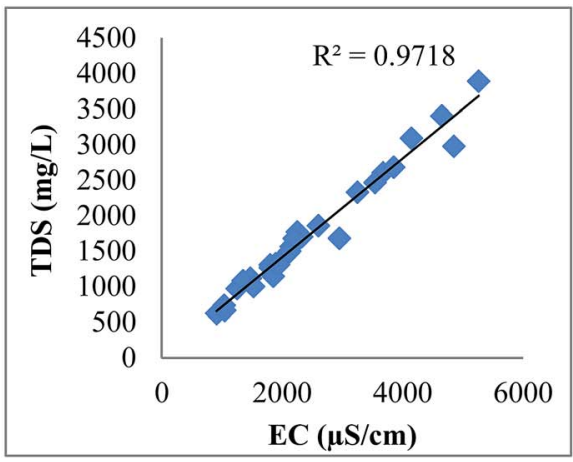

(a)

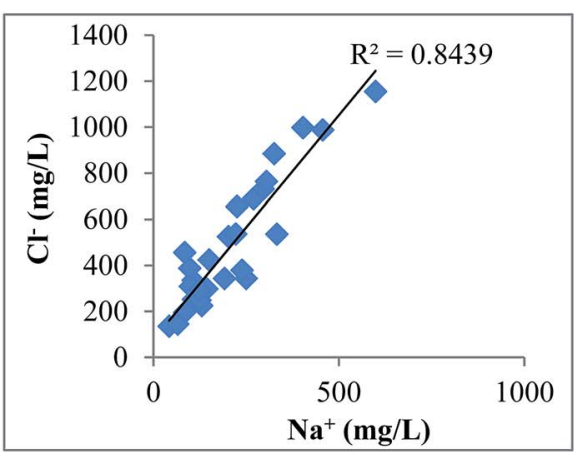

(c)

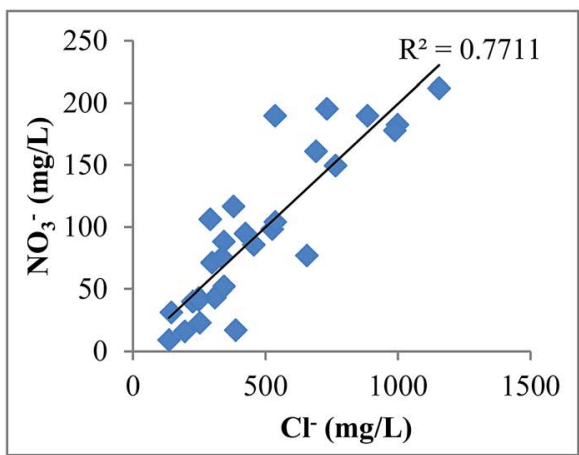

(e)

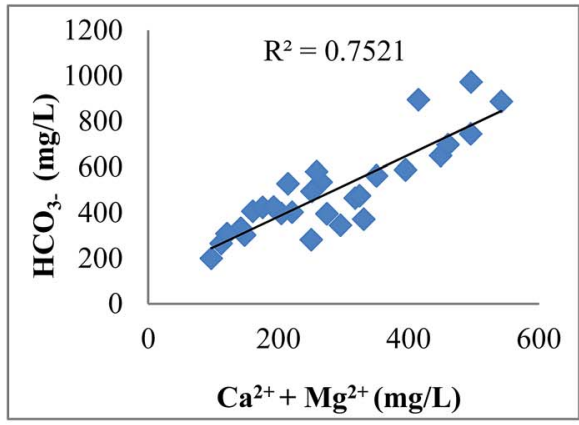

(g)

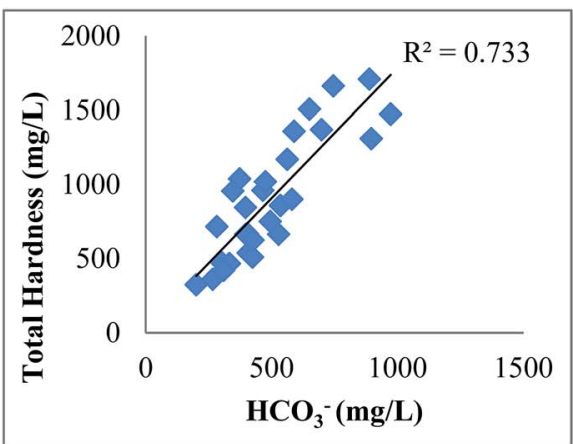

(b)

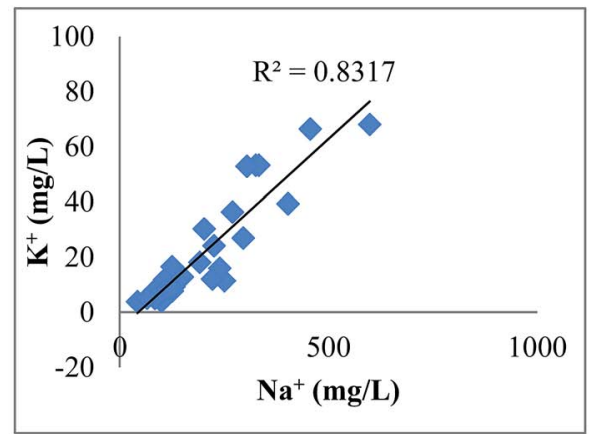

(d)

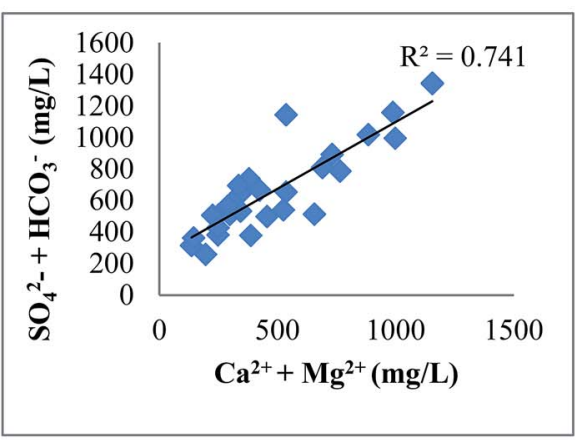

(f)

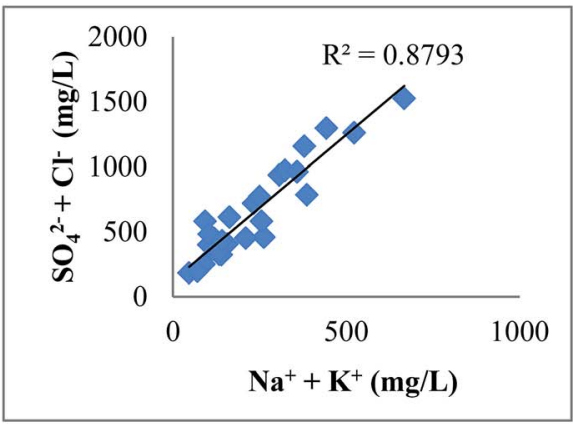

(h)

Fig. 8 Correlation of (a) EC with TDS, (b) $\mathrm{HCO}_{3}{ }^{-}$with $\mathrm{TH}$, (c) $\mathrm{Na}^{+}$with $\mathrm{Cl}^{-}$, (d) $\mathrm{Na}^{+}$with $\mathrm{K}^{+}$, (e) $\mathrm{Cl}^{-}$with $\mathrm{NO}_{3}^{-}$, (f) $\mathrm{Ca}^{2+}+\mathrm{Mg}^{2+}$ with $\mathrm{HCO}_{3}{ }^{-}$, (g) $\mathrm{Ca}^{2+}+\mathrm{Mg}^{2+}$ with $\mathrm{SO}_{4}{ }^{2-}+\mathrm{HCO}_{3}{ }^{-}$and (h) $\mathrm{Na}^{+}+\mathrm{K}^{+}$with $\mathrm{SO}_{4}{ }^{2-}+\mathrm{Cl}^{-}$.

humans, and it is necessary in small amounts in our diet to ensure good health. However, the excessive ingestion of $\mathrm{Cu}$ can cause serious toxicological concerns, such as vomiting, diarrhea, stomach cramps and nausea, or even death. ${ }^{53}$ The concentration of copper in the investigated samples varied from BDL-0.26 $\mathrm{mg} \mathrm{L}^{-1}$ with an average of $0.018 \mathrm{mg} \mathrm{L}^{-1}$. The major 
sources of copper in groundwater are the corrosion of household plumbing systems and the erosion of natural deposits. ${ }^{42}$ The concentrations of copper were well within the permissible limits designated by the BIS and WHO standards. Thus, the groundwater in the studied area can be considered safe in terms of zinc and copper content.

\subsection{Hydrochemical facies}

Hydrochemical facies can be defined as zones within a groundwater system with unique combinations of cation and anion concentrations. ${ }^{54}$ This concept is useful for developing a model to explain the genesis and distribution of principal groundwater types. ${ }^{55}$ The geochemical evolution of the groundwater and its relationship with different dissolved ions can be understood by plotting the geochemical data on a Piper ${ }^{56}$ trilinear diagram. The triangular cationic zone of the Piper diagram revealed that most of the groundwater samples (89\%) fall into no dominant class. One of the samples was classified as $\mathrm{a} \mathrm{Ca}^{2+}$ zone and two were classified as $\mathrm{Mg}^{2+}$ zones in the cationic triangle, whereas in the anionic triangle, about $50 \%$ of the samples fell into no dominant zone. The rest of the samples fell into the $\mathrm{Cl}^{-}$zone in the anion triangle (Fig. 6). Moreover, the plotted points of $93 \%$ of the groundwater samples fell in zone 9 , indicating an intermediate (mixed) chemical character of the groundwater, with none of the cation-anion pairs being dominant in the chemical composition. About $7 \%$ of the samples fell into zone 6, suggesting non-carbonate hardness. The characteristics of water in each zone of the Piper trilinear diagram are shown in Table 3. Based on the dominance of different cations and anions in the groundwater, a major hydrogeochemical water type in the study area can be defined as $\mathrm{Ca}^{2+}-\mathrm{Mg}^{2+}-\mathrm{Cl}^{-}-$ $\mathrm{SO}_{4}{ }^{2-}$. A Gibbs diagram representing the ratio of $\mathrm{Na}^{+}+\mathrm{K}^{+} /\left(\mathrm{Na}^{+}+\right.$ $\left.\mathrm{K}^{+}+\mathrm{Ca}^{2+}\right)$ and $\mathrm{Cl}^{-}+\mathrm{NO}_{3}^{-} /\left(\mathrm{Cl}^{-}+\mathrm{NO}_{3}{ }^{-}+\mathrm{HCO}_{3}{ }^{-}\right)$as a function of TDS can be used to understand the functional sources of dissolved chemical constituents, such as precipitation/rock/ evaporation dominance..$^{57}$ The plot of the geochemical data on Gibbs diagrams suggested rock weathering as a major driving force, with evaporation being a minor influence, thus controlling the groundwater chemistry of the study area (Fig. 7).

\subsection{Correlation analysis of groundwater samples}

Table 4 shows the statistical correlation matrix of various elements. Pearson correlation is a common statistical test used for determining the extent of association or correlation between two variables. In this study, there is a high correlation between various anions and cations due to anthropogenic activity in the surrounding area of the sampling site.

The correlation of various elements is shown in Fig. 8. EC shows strong correlation with TDS (0.99), $\mathrm{Cl}^{-}(0.97), \mathrm{HCO}_{3}{ }^{-}$ (0.90), $\mathrm{SO}_{4}{ }^{2-}(0.94), \mathrm{NO}_{3}{ }^{-}(0.94), \mathrm{Ca}^{2+}(0.88), \mathrm{Mg}^{2+}(0.80), \mathrm{Na}^{+}$ $(0.93), \mathrm{K}^{+}(0.93)$ and $\mathrm{TH}(0.95)$. The perfect correlation between EC and TDS indicated the high content of dissolved ions in the water. The total dissolved solids include organic and inorganic salts, such as $\mathrm{Ca}^{2+}, \mathrm{Mg}^{2+}, \mathrm{Na}^{+}, \mathrm{K}^{+}, \mathrm{Cl}^{-}, \mathrm{HCO}_{3}{ }^{-}$and $\mathrm{SO}_{4}{ }^{2-}$. The correlation coefficient of TDS with $\mathrm{Ca}^{2+}, \mathrm{Mg}^{2+}, \mathrm{Na}^{+}, \mathrm{K}^{+}, \mathrm{Cl}^{-}$, $\mathrm{HCO}_{3}{ }^{-}, \mathrm{SO}_{4}{ }^{2-}, \mathrm{NO}_{3}{ }^{-}$and $\mathrm{TH}$ is very high, showing the
Table 5 Principal component analysis of groundwater samples in Agra city $^{a}$

\begin{tabular}{|c|c|c|c|c|}
\hline \multirow[b]{2}{*}{ Variables } & \multicolumn{4}{|c|}{ Component } \\
\hline & PC1 & PC2 & PC3 & PC4 \\
\hline $\mathrm{pH}$ & 0.36 & 0.18 & 0.59 & 0.32 \\
\hline EC & 0.99 & -0.06 & 0.00 & -0.06 \\
\hline DO & -0.03 & -0.41 & 0.33 & 0.73 \\
\hline Turbidity & 0.28 & 0.45 & 0.34 & 0.17 \\
\hline TDS & 0.99 & -0.09 & -0.02 & -0.04 \\
\hline $\mathrm{F}^{-}$ & 0.33 & 0.40 & 0.58 & -0.46 \\
\hline $\mathrm{Cl}^{-}$ & 0.94 & -0.22 & -0.06 & -0.09 \\
\hline $\mathrm{HCO}_{3}{ }^{-}$ & 0.94 & 0.12 & 0.10 & 0.04 \\
\hline $\mathrm{SO}_{4}{ }^{2-}$ & 0.95 & -0.14 & -0.04 & -0.02 \\
\hline $\mathrm{NO}_{3}^{-}$ & 0.97 & 0.00 & -0.01 & -0.03 \\
\hline $\mathrm{Ca}^{2+}$ & 0.87 & -0.14 & -0.03 & -0.08 \\
\hline $\mathrm{Mg}^{2+}$ & 0.83 & -0.01 & 0.07 & 0.12 \\
\hline $\mathrm{Na}^{+}$ & 0.93 & -0.08 & -0.08 & -0.11 \\
\hline $\mathrm{K}^{+}$ & 0.93 & -0.03 & -0.11 & 0.09 \\
\hline $\mathrm{TH}$ & 0.96 & -0.08 & 0.03 & 0.03 \\
\hline $\mathrm{Zn}$ & 0.36 & 0.19 & -0.48 & 0.08 \\
\hline $\mathrm{Cu}$ & 0.37 & 0.71 & -0.22 & 0.05 \\
\hline $\mathrm{Fe}$ & -0.12 & 0.83 & 0.07 & -0.08 \\
\hline Mn & 0.20 & 0.60 & -0.36 & 0.52 \\
\hline Eigenvalue (\%) & 10.30 & 2.28 & 1.37 & 1.22 \\
\hline$\%$ of variance & 54.25 & 12.03 & 7.23 & 6.43 \\
\hline Cumulative \% & 54.25 & 66.28 & 73.51 & 79.95 \\
\hline
\end{tabular}

${ }^{a}$ Highlighted values are considered as significant.

dissolution of salts in groundwater from anthropogenic sources such as industrial effluent and domestic discharge. This correlation of TDS with $\mathrm{Na}-\mathrm{HCO}_{3}-\mathrm{Cl}$ or $\mathrm{Na}-\mathrm{HCO}_{3}-\mathrm{Mg}$ may be due to the high fluoride concentration as studied by Deng et al..$^{58}$ The positive correlation of total hardness with bicarbonate, calcium, and magnesium content shows that hardness is due to the presence of bicarbonate salts of calcium and magnesium. There is also a strong correlation of $\mathrm{Cl}^{-}$with $\mathrm{HCO}_{3}{ }^{-}, \mathrm{SO}_{4}{ }^{2-}, \mathrm{NO}_{3}{ }^{-}, \mathrm{Ca}^{2+}, \mathrm{Mg}^{2+}, \mathrm{Na}^{+}, \mathrm{K}^{+}$and $\mathrm{TH} ; \mathrm{HCO}_{3}{ }^{-}$with $\mathrm{SO}_{4}{ }^{2-}, \mathrm{NO}_{3}{ }^{-}, \mathrm{Ca}^{2+}, \mathrm{Mg}^{2+}, \mathrm{Na}^{+}, \mathrm{K}^{+}$and $\mathrm{TH} ; \mathrm{SO}_{4}{ }^{2-}$ with $\mathrm{NO}_{3}{ }^{-}$, $\mathrm{Ca}^{2+}, \mathrm{Mg}^{2+}, \mathrm{Na}^{+}, \mathrm{K}^{+}$and $\mathrm{TH} ; \mathrm{NO}_{3}{ }^{-}$with $\mathrm{Ca}^{2+}, \mathrm{Mg}^{2+}, \mathrm{Na}^{+}, \mathrm{K}^{+}$and TH; $\mathrm{Ca}^{2+}$ with $\mathrm{Na}^{+}, \mathrm{K}^{+}$and $\mathrm{TH} ; \mathrm{Mg}^{2+}$ with $\mathrm{K}^{+}$and $\mathrm{TH} ; \mathrm{Na}^{+}$with $\mathrm{K}^{+}$

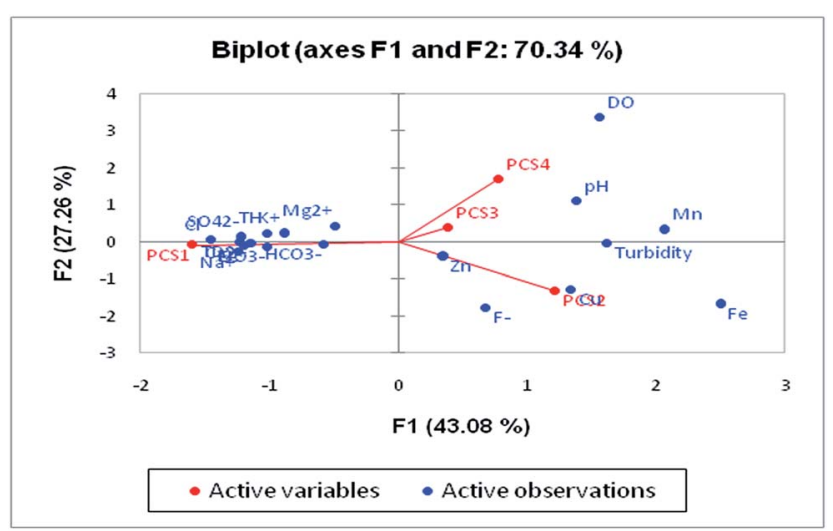

Fig. 9 Loadings of the first four factors in the biplot showing the PCA of the water quality variables. 
and $\mathrm{TH}$; and $\mathrm{K}^{+}$with $\mathrm{TH}$. These various correlations indicated that the process of weathering, exchangeable ions and reduction/oxidation, in conjunction with anthropogenic activity, may have caused the dissolution of salts in groundwater. ${ }^{59}$ Samantara et al. $^{42}$ also observed a similar correlation between sulphate and chloride which might be due to the similar biochemical pathways that they follow. There is also a significant correlation between $\mathrm{Ca}^{2+}$ and $\mathrm{Mg}^{2+}$ and between $\mathrm{Mg}^{2+}$ and $\mathrm{Na}^{+}$.

\subsection{Principal component analysis}

Principal component analysis (PCA) is a statistical analysis technique to identify patterns of data to make it easy to explore. It involves multivariate analysis which transforms a large set of correlated variables into a small set of uncorrelated variables. The tool is based on covariance which represents the interrelationships of the variable. ${ }^{60}$ It is also known as a dimensionless reduction tool because it constructs a new set of variables by reducing a large dataset. PCA can be used for the association of chemical compositions defined by one or more variable loadings on the factor that influences groundwater quality. A factor loading value close to \pm 1 indicates a strong correlation between the variables and the factor, while values $> \pm 0.5$ are considered significant.

Four major eigenvalues (PC1, PC2, PC3 and PC4) were found in 28 groundwater samples for 19 parameters which could explain $79.95 \%$ of the variability. PC1 has the maximum variance in the data, followed by PC2, PC3 and PC4, respectively (Table 5). There is $54.25 \%$ of the variation in $\mathrm{PC} 1$ which exhibits significant loadings of EC, TDS, $\mathrm{Cl}^{-}, \mathrm{HCO}_{3}{ }^{-}, \mathrm{SO}_{4}{ }^{2-}, \mathrm{NO}_{3}{ }^{-}, \mathrm{Ca}^{2+}, \mathrm{Mg}^{2+}, \mathrm{Na}^{+}$, $\mathrm{K}^{+}$and TH. PC1 mainly represented the major anions and cations resulting from natural and anthropogenic sources. The natural processes include water-rock interaction and the weathering of minerals in the aquifer, ${ }^{61}$ while the anthropogenic sources are attributed to industrial effluents, municipal solid waste and untreated sewage discharge. $\mathrm{NO}_{3}{ }^{-}$loading is explained by onsite sanitation and nutrient contamination from an unsewered urban environment. PC2 was influenced by $\mathrm{Cu}$ and $\mathrm{Fe}$ and accounted for $12.03 \%$ of the total variance. The sources of these ions are anthropogenic activity in the study area. The high loading of Fe is
Table 7 Relative weights of the major components ${ }^{a}$

\begin{tabular}{|c|c|c|c|}
\hline Chemical parameters & $\begin{array}{l}\text { Standards } \\
\text { (BIS 2012) }\end{array}$ & Weight $\left(w_{i}\right)$ & Relative weight $\left(W_{i}\right)$ \\
\hline $\mathrm{pH}$ & 8.5 & 4 & 0.07 \\
\hline Turbidity & 5 & 4 & 0.07 \\
\hline $\begin{array}{l}\text { Total dissolved solids } \\
\text { (TDS) }\end{array}$ & 500 & 5 & 0.08 \\
\hline Fluoride $\left(\mathrm{F}^{-}\right)$ & 1.5 & 5 & 0.08 \\
\hline Chloride $\left(\mathrm{Cl}^{-}\right)$ & 250 & 5 & 0.08 \\
\hline Nitrate $\left(\mathrm{NO}_{3}{ }^{-}\right)$ & 50 & 5 & 0.08 \\
\hline Sulphate $\left(\mathrm{SO}_{4}{ }^{2-}\right)$ & 200 & 5 & 0.08 \\
\hline Bicarbonate $\left(\mathrm{HCO}_{3}{ }^{-}\right)$ & 200 & 1 & 0.02 \\
\hline Calcium $\left(\mathrm{Ca}^{2+}\right)$ & 75 & 3 & 0.05 \\
\hline Magnesium $\left(\mathrm{Mg}^{2+}\right)$ & 30 & 3 & 0.05 \\
\hline Total hardness (TH) & 100 & 2 & 0.03 \\
\hline Zinc (Zn) & 5 & 4 & 0.07 \\
\hline Copper (Cu) & 0.05 & 5 & 0.08 \\
\hline Iron $(\mathrm{Fe})$ & 0.3 & 4 & 0.07 \\
\hline \multirow[t]{2}{*}{ Manganese (Mn) } & 0.1 & 5 & 0.083 \\
\hline & & $\Sigma w_{i}=60$ & $\Sigma W_{i}=1.00$ \\
\hline
\end{tabular}

${ }^{a}$ All parameters are in $\mathrm{mg} \mathrm{L}^{-1}$ except for $\mathrm{pH}$ and turbidity.

due to the leaching of Fe-rich sediments such as laterites and lateritic soils into the groundwater. PC3 contributes $7.23 \%$ of the total variance with significant loadings of fluoride and $\mathrm{pH}$ which suggested that fluoride is influenced by $\mathrm{pH}$. The leaching of fluoride from florahalite ore and the continuous dumping of untreated sewage into the Yamuna river is responsible for the significant loadings of fluoride. PC4 shows moderate loadings of DO, trace metals and Mn with a total variance of $6.43 \%$. The presence of $\mathrm{Mn}$ in groundwater can be associated with untreated sewage and landfill leachate. Biplots of the first four components are shown in Fig. 9.

\subsection{Evaluation and assessment of health risk due to trace metals}

The dietary health risk was estimated for all of the investigated metals. The non-carcinogenic health risk in adults due to exposure to trace metals through ingestion is shown in Table 6. The ADD was calculated for minimum, maximum and mean

Table 6 Average daily dose and hazard quotient indices with reference dose for studied trace metals

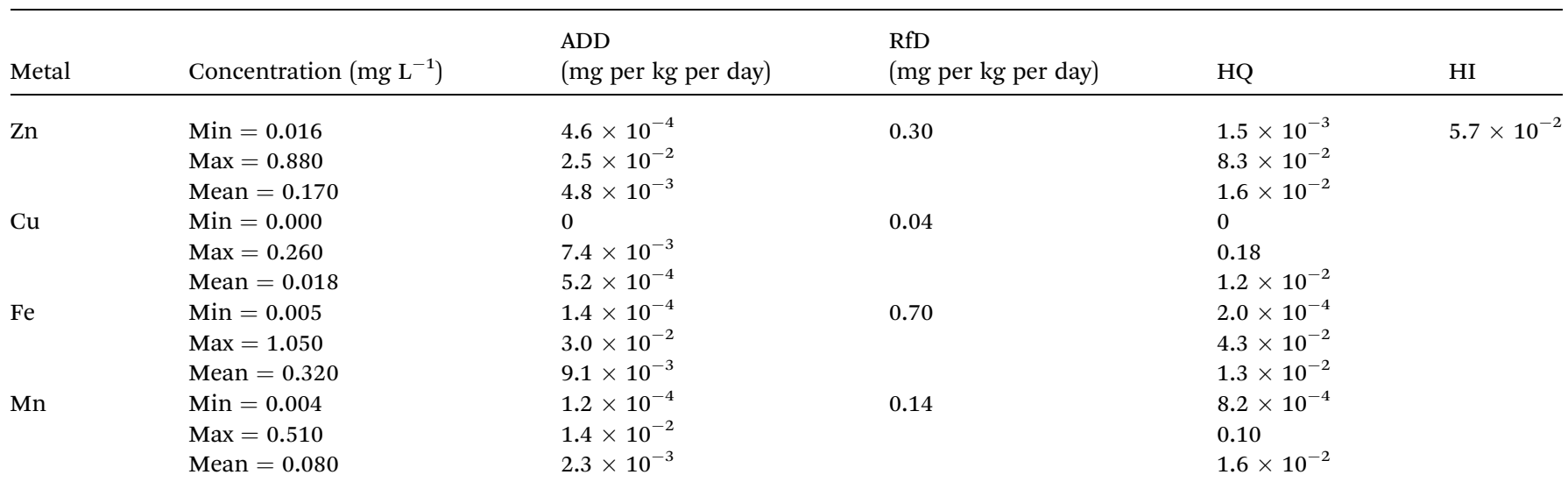


Table 8 Classification of water quality based on the WQI range and the $\%$ of samples in each respective category ${ }^{29,33,62}$

\begin{tabular}{lll}
\hline WQI range & Type of water & \% of samples \\
\hline$<50$ & Excellent water & Nil \\
$50-100$ & Good water & Nil \\
$100-200$ & Poor water & 46.42 \\
$200-300$ & Very poor water & 28.57 \\
$>300$ & Unfit for drinking purposes & 25
\end{tabular}

concentrations of $\mathrm{Zn}, \mathrm{Cu}, \mathrm{Fe}$ and $\mathrm{Mn}$. The average daily dose depends on the water consumption, weight and age of an individual. The HQ values for all trace metals were less than unity which indicated that these metals do not pose any adverse health effect to humans when groundwater in the studied areas is consumed by adults. The metals in order of decreasing HQ were $\mathrm{Mn}>\mathrm{Zn}>\mathrm{Fe}>\mathrm{Cu}$.

The calculated hazard index across all metals served as a conservative assessment tool to estimate high-end risk rather than low-end risk in order to protect the public. This served as a screening value to determine whether the exposure to heavy metals in the groundwater may pose a significant health risk to the inhabitants. The estimated HI value was less than one, i.e. $5.7 \times 10^{-2}$ (Table 6), therefore exposure to these elements through groundwater is not likely to exert a negative or cumulative adverse risk on the inhabitants in the study area.

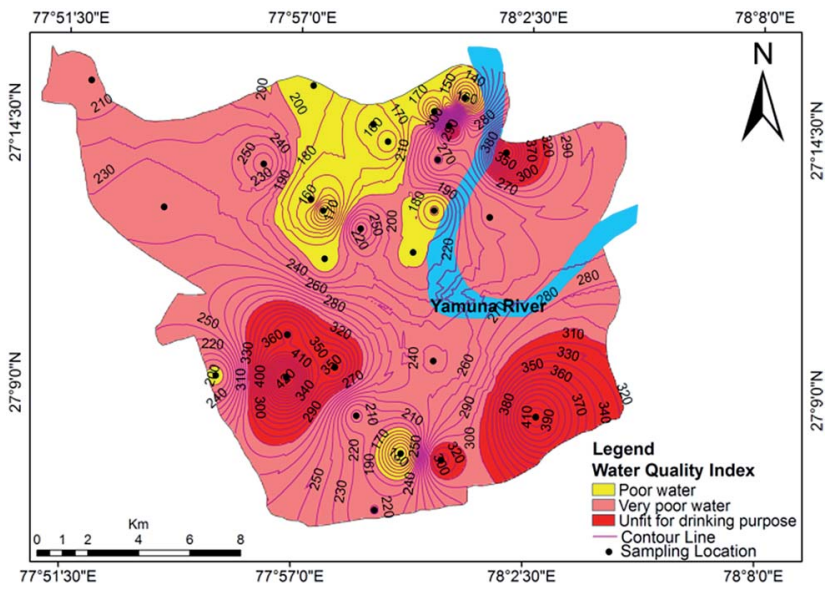

Fig. 10 Water quality index map for groundwater in Agra.

\subsection{Evaluation of groundwater quality using the water quality index (WQI)}

The relative weights of the major components are computed and shown in Table 7. The computed WQI values were classified into different categories, as shown in Table 8. The WQI values at different locations are given in Table 9 and the spatial variation of the WQI is mapped in Fig. 10. The WQI values for groundwater in Agra city ranged from 109 to 455 with an average value of 240. The high values of WQI were mainly due to high TDS, $\mathrm{F}^{-}$, $\mathrm{Cl}^{-}, \mathrm{NO}_{3}{ }^{-}, \mathrm{Mg}^{2+}, \mathrm{Na}^{+}$and $\mathrm{TH}$. As per WQI categorization, the

Table 9 Water quality index (WQI) values of groundwater in Agra

\begin{tabular}{|c|c|c|c|c|c|c|}
\hline S. no. & Place name & Source of water & Latitude & Longitude & WQI & Description \\
\hline 1 & Sikandra & Hand pump & $27.25^{\circ}$ & $77.86^{\circ}$ & 207 & Very poor \\
\hline 2 & Khandari & Hand pump & $27.22^{\circ}$ & $77.93^{\circ}$ & 256 & Very poor \\
\hline 3 & Dayal Bagh & Hand pump & $27.25^{\circ}$ & $77.95^{\circ}$ & 194 & Poor water \\
\hline 4 & Langre ki Chowki & Tube well & $27.23^{\circ}$ & $78.00^{\circ}$ & 272 & Very poor \\
\hline 5 & Balkeshwar & Hand pump & $27.24^{\circ}$ & $78.00^{\circ}$ & 365 & Unsuitable \\
\hline 6 & Rambagh & Hand pump & $27.23^{\circ}$ & $78.03^{\circ}$ & 410 & Unsuitable \\
\hline 7 & Belanganj & Hand pump & $27.21^{\circ}$ & $78.00^{\circ}$ & 167 & Very poor \\
\hline 8 & Daresi & Hand pump & $27.19^{\circ}$ & $77.99^{\circ}$ & 194 & Poor water \\
\hline 9 & Shahganj & Hand pump & $27.16^{\circ}$ & $77.94^{\circ}$ & 361 & Unsuitable \\
\hline 10 & Agra Cantt & Tube well & $27.12^{\circ}$ & $78.00^{\circ}$ & 325 & Unsuitable \\
\hline 11 & Baluganj & Hand pump & $27.16^{\circ}$ & $78.00^{\circ}$ & 237 & Poor water \\
\hline 12 & Tajganj & Hand pump & $27.14^{\circ}$ & $78.04^{\circ}$ & 414 & Unsuitable \\
\hline 13 & Bundu Katra & Hand pump & $27.10^{\circ}$ & $77.98^{\circ}$ & 219 & Poor water \\
\hline 14 & Loha Mandi & Hand pump & $27.21^{\circ}$ & $77.89^{\circ}$ & 237 & Poor water \\
\hline 15 & Kamla Nagar & Hand pump & $27.24^{\circ}$ & $78.00^{\circ}$ & 135 & Poor water \\
\hline 16 & Hariparwat & Hand pump & $27.21^{\circ}$ & $77.95^{\circ}$ & 172 & Poor water \\
\hline 17 & St. John's College & Hand pump & $27.21^{\circ}$ & $77.96^{\circ}$ & 109 & Poor water \\
\hline 18 & Suresh Nagar & Tube well & $27.24^{\circ}$ & $77.97^{\circ}$ & 160 & Very poor \\
\hline 19 & Itmad-ud-Daula & Tube well & $27.21^{\circ}$ & $78.02^{\circ}$ & 251 & Very poor \\
\hline 20 & Sadar Bazar & Hand pump & $27.14^{\circ}$ & $77.97^{\circ}$ & 206 & Very poor \\
\hline 21 & Sultanpura & Hand pump & $27.15^{\circ}$ & $77.94^{\circ}$ & 455 & Unsuitable \\
\hline 22 & Gandhi Nagar & Hand pump & $27.23^{\circ}$ & $77.98^{\circ}$ & 151 & Poor water \\
\hline 23 & Nai Ki Mandi & Hand pump & $27.19^{\circ}$ & $77.96^{\circ}$ & 190 & Poor water \\
\hline 24 & Mantola & Tube well & $27.20^{\circ}$ & $77.97^{\circ}$ & 256 & Very poor \\
\hline 25 & Rajwara & Tube well & $27.25^{\circ}$ & $78.01^{\circ}$ & 110 & Poor water \\
\hline 26 & Namner & Hand pump & $27.15^{\circ}$ & $77.96^{\circ}$ & 357 & Unsuitable \\
\hline 27 & Naulakha & Hand pump & $27.12^{\circ}$ & $77.99^{\circ}$ & 131 & Poor water \\
\hline 28 & Idgah Colony & Hand pump & $27.15^{\circ}$ & $77.91^{\circ}$ & 194 & Poor water \\
\hline
\end{tabular}


studied water samples fall under 'poor', 'very poor' and 'unsuitable' categories, with values of $46.42 \%, 28.57 \%$ and $25 \%$, respectively. The groundwater at Langre ki Chowki, Agra Cantt, Namner, Shahganj, Balkeshwar, Rambagh, Tajganj and Sultanpura was unfit for drinking purposes. No sample was observed in 'excellent' or 'good' categories of groundwater quality. This indicated that the groundwater in the study area is unsafe for drinking purposes, and hence its remediation and treatment is necessary prior to human consumption.

\section{Conclusions}

Groundwater quality was determined in the present study at different locations in Agra city for drinking purposes. The findings of this study concluded that the groundwater in the studied area is unsuitable for drinking purposes. The various physicochemical parameters of most of the groundwater samples exceeded the BIS and WHO permissible limits for drinking water, which may substantially harm the health of the residents in the area. Anthropogenic sources such as industrial waste, untreated sewage water, municipal solid waste dumping and automobile emissions might be the factors causing the excessive concentration of various parameters. The cationic concentrations of $\mathrm{Mg}^{2+}$ and $\mathrm{Na}^{+}$as well as the anionic concentrations of $\mathrm{HCO}_{3}{ }^{-}$and $\mathrm{Cl}^{-}$are dominant in the groundwater. The groundwater is laden with an objectionable concentration of cations and anions which may have been derived from a number of different sources, i.e.mineralization, the chemical weathering of rock, mine tailings and sewage contamination. Gibbs diagrams suggest rock weathering as a major driving force along with evaporation as a minor influence, thus controlling the groundwater chemistry. The concentrations of the studied trace metals ( $\mathrm{Zn}, \mathrm{Fe}$, $\mathrm{Cu}$ and $\mathrm{Mn}$ ) in the groundwater samples complied with the WHO and BIS standards for drinking water. The value of the hazard index was $5.7 \times 10^{-2}$ for trace metals, which is much less than 1 , indicating that there will be no potential health effects from trace metals. On the basis of the water quality index, almost half of the samples belong to the 'poor' category and the other half of the samples fall in the 'very poor' and 'unfit for drinking purposes' categories. Therefore, appropriate treatment and remediation techniques are required prior to human consumption. Spatial distribution maps communicated possible information regarding the overall water quality distribution in the study area, and they are a useful technique for monitoring, management and future modeling with the aid of a GIS tool. This study strongly recommends continuous groundwater monitoring in and around the study area for planning and implementation in order to meet water supply demand without compromising the ability of future generations to meet water quality requirements.

\section{Conflicts of interest}

There are no conflicts of interest to declare.

\section{Acknowledgements}

The authors would like to thank Dr Ashwani Kumar Tiwari from the Department of Environment, Land and Infrastructure Engineering, Politecnico di Torino, for his help in preparing the GIS map and statistical assistance. We give our hearty thanks to Richard Chadd, Senior Ecologist at the Environment Agency, UK, for his valuable suggestions and guidance.

\section{References}

1 P. O. Agbaire and C. G. Obi, J. Appl. Sci. Environ. Manage., 2009, 13, 55-57.

2 N. Gupta, K. K. Yadav, V. Kumar and D. Singh, Int. J. ChemTech Res., 2013, 5, 528-531.

3 D. K. Tank and C. C. P. Singh, Nat. Sci., 2010, 8, 1-7.

4 K. K. Yadav, N. Gupta, V. Kumar, S. Arya and D. Singh, Recent Res. Sci. Technol., 2012, 4, 51-54.

5 R. Srinivas, P. Bhakar and A. P. Singh, Aquatic Procedia, 2015, 4, 1023-1030.

6 N. Gupta, K. K. Yadav and V. Kumar, J. Environ. Sci., 2015, 37, 206-217.

7 A. K. Tiwari, A. K. Singh and M. P. Singh, Appl. Water Sci., 2017, 7, 1609-1623.

8 P. Prabhakaran, M. A. Ashraf and W. S. Aqma, RSC Adv., 2016, 6, 109862-109877.

9 M. Lenin, M. S. Kumar and T. R. Mycin, Int. J. Life Sci. Biotechnol. Pharma Res., 2014, 3(1), 151-160.

10 K. K. Yadav, N. Gupta, V. Kumar and J. K. Singh, Indian J. Environ. Prot., 2017, 37(1), 65-84.

11 K. K. Yadav, J. K. Singh, N. Gupta and V. Kumar, J. Mater. Environ. Sci., 2017, 8(2), 740-757.

12 K. Mohankumar, V. Hariharan and N. P. Rao, J. Clin. Diagn. Res., 2016, 10, BC05-BC07.

13 M. Jaishankar, T. Tseten, N. Anbalagan, B. B. Mathew and K. N. Beeregowda, Interdiscip. Toxicol., 2014, 7(2), 60-72.

14 R. Gürkan, H. I. Ulusoy and M. Akçay, Arabian J. Chem., 2017, 10, S450-S460.

15 E. Satyanarayana, D. Ratnakar and M. Muralidhar, Hydrol.: Curr. Res., 2016, 7, 253.

16 C. Prerna, P. K. Pathak, D. Singh and A. K. Srivastava, in Emerging Trends in Science, Engineering, and Technology. Lecture Notes in Mechanical Engineering, S. Sathiyamoorthy, B. Caroline and J. Jayanthi, Springer, India, 2012, pp. 541549.

17 V. Kumar, S. Singh and G. Krishan, Curr. World Environ., 2017, 12(1), 61-67.

18 GWYB, Ground Water Year Book, Uttar Pradesh, 2014-15, http://www.cgwb.gov.in/Regions/GW-year-Books/GWYB2014-15/GWYB\%202014-15\%20U.P.pdf.

19 DGWB, District Ground Water Brochure, Agra District, Uttar Pradesh, 2012,http://www.cgwb.gov.in/District_Profile/UP/ Agra.pdf.

20 R. Quamar, C. Jangam, J. Veligeti, P. Chintalapudi and R. Janipella, Appl. Water Sci., 2017, 7(8), 4375-4386.

21 A. K. Misra, Int. J. Sustainable Built Environ., 2013, 2(1), 7388. 
22 M. R. K. P. Rao and B. C. Negi, J. Indian Geophys. Union, 2003, $7(4), 219-222$.

23 GDUP, Groundwater Stress - City Agra (An Overview of Urban Aquifers and Groundwater Crisis), Groundwater Department Uttar Pradesh, 2017, http://upgwd.gov.in/MediaGallery/ Ground\%20Water\%20Stress\%20-\%20City\%20Agra.pdf.

24 APHA, Standard Methods for the Examination of Water and Wastewater Analysis, American Public Health Association, Washington, DC, 2005.

25 USEPA, Risk Assessment Guidance for Superfund: Volume III Part A, Process for Conducting Probability Risk Assessment, US Environmental Protection Agency, Washington,DC, 2001.

26 USEPA, Guidelines for Carcinogen Risk Assessment, U. S. Environmental Protection Agency, Washington, DC, 2005.

27 J. N. Edokpayi, A. M. Enitan, N. Mutileni and J. O. Odiyo, Chem. Cent. J., 2018, 12, 2.

28 K. K. Yadav, N. Gupta, V. Kumar, S. Sharma and S. Arya, Int. J. Sci. Basic Appl. Res., 2015, 19(1), 241-250.

29 A. K. Tiwari, A. K. Singh and M. K. Mahato, Sustainable Water Resources Management, 2017, 1-16.

30 I. Jasmin and P. Mallikarjuna, Environ. Monit. Assess., 2014, 186(2), 935-948.

31 A. K. Verma and T. N. Singh, Environ. Earth Sci., 2013, 69, 821-829.

32 R. Khan and D. C. Jhariya, J. Geol. Soc. India, 2017, 90(1), 6976.

33 P. Sharma, P. K. Meher, A. Kumar, Y. P. Gautam and K. P. Mishra, Sustainability of Water Quality and Ecology, 2014, 3-4, 67-76.

34 BIS, Indian Standard Specification for Drinking Water, Bureau of Indian Standards, New Delhi, 2012.

35 G. Gnanachandrasamy, T. Ramkumar, S. Venkatramanan, S. Vasudevan, S. Y. Chung and M. Bagyaraj, Appl. Water Sci., 2015, 5(1), 39-55.

36 S. Rose and A. Long, Groundwater Monit. Rem., 1988, 8(1), 93-97.

37 WHO, Guidelines for Drinking-water Quality, 3rd ed., Vol. 1, Recommendations, World Health Organisation, Geneva, 1997.

38 S. Selvakumar, N. Chandrasekar and G. Kumar, Water Resources and Industry, 2017, 17, 26-33.

39 C. N. Sawyer and P. L. McCarty, Chemistry for Sanitary Engineers, McGraw Hill, New York, 1967.

$40 \mathrm{FAO} / \mathrm{WHO}$, A Model for Establishing Upper Levels of Intake for Nutrients and Related Substances, Technical Workshop on
Nutrient Risk Assessment, World Health Organization, Geneva, 2006.

41 A. K. Singh, G. C. Mondal, S. Kumar, T. B. Singh, B. K. Tewary and A. Sinha, Environ. Geol., 2008, 54(4), 745-758.

42 M. K. Samantara, R. K. Padhi, M. Sowmya, P. Kumaran and K. K. Satpathy, Groundwater for Sustainable Development, 2017, 5, 49-58.

43 Y. Han, G. Wang, C. A. Cravotta, W. Hu, Y. Bian, Z. Zhang and Y. Liu, Hydrol. Processes, 2013, 27(16), 2247-2257.

44 D. Majumdar and N. Gupta, Indian J. Environ. Health, 2000, 2, 28-39.

45 D. Qu, C. Wang, Y. Wang, R. Zhou and H. Ren, RSC Adv., 2015, 5, 5149-5157.

46 Y. Liu, C. Feng, N. Chen, Y. Sheng, S. Dong, C. Hao and K. Lei, $R S C A d v$., 2016, 6, 108375-108383.

47 L. Chu and J. Wang, RSC Adv., 2017, 7, 53454-53462.

48 K. K. Yadav, N. Gupta, V. Kumar, S. A. Khan and A. Kumar, Environ. Int., 2018, 111, 80-108.

49 A. Bhatnagar, E. Kumar and M. Sillanpaa, Chem. Eng. J., 2011, 171(3), 811-840.

50 T. Bacquart, S. Frisbie, E. Mitchell, E. Grigg, C. Cole, C. Small and B. Sarkar, Sci. Total Environ., 2015, 517, 232-245.

51 W. Mareta and H. H. Sandsteada, J. Trace Elem. Med. Biol., 2006, 20, 3-18.

52 S. H. Frisbie, E. J. Mitchell, H. Dustin, D. M. Maynard and B. Sarkar, Environ. Health Perspect., 2012, 120(6), 775-778.

53 H. N. M. E. Mahmud, A. K. O. Huq and R. B. Yahya, RSC Adv., 2016, 6, 14792-14798.

54 P. L. Younger, Groundwater in the Environment: An Introduction, Blackwell Publishing, USA, 2007.

55 V. K. Singh, D. S. Bikundia, A. Sarswat and D. Mohan, Environ. Monit. Assess., 2012, 184(7), 4473-4488.

56 A. M. Piper, Trans., Am. Geophys. Union, 1944, 25(6), 914-928.

57 R. J. Gibbs, Science, 1970, 170, 1088-1090.

58 Y. Deng, Y. Wang and T. Ma, Appl. Geochem., 2009, 24, 587599.

59 N. S. Rao, Environ. Geol., 2002, 41(5), 552-562.

60 I. T. Jolliffe, Principal Component Analysis, Springer, New York, 2002.

61 D. Purushotham, M. R. Prakash and A. N. Rao, Environ. Earth Sci., 2011, 62, 1707-1721.

62 C. R. Ramakrishnaiah, C. Sadashivaiah and G. Ranganna, Eur. J. Chem., 2009, 6, 523-530. 